\title{
HEPATITIS B: EPIDEMIOLOGICAL, IMMUNOLOGICAL, AND SEROLOGICAL CONSIDERATIONS EMPHASIZING MUTATION
}

\author{
Marcelo El Khouri and Vera Aparecida dos Santos
}

KHOURI ME et al. Hepatitis B: epidemiological, immunological, and serological considerations emphasizing mutation.

Rev. Hosp. Clín. Fac. Med. S. Paulo 59(4):216-224, 2004.

The global prevalence of hepatitis B virus is estimated to be 350 million chronic carriers, varying widely from low $(<2 \%$, as in Western Europe, North America, New Zealand, Australia, and Japan) to high ( $>8 \%$ as in Africa, Southeast Asia, and China). The overall prevalence in Brazil is about $8 \%$. There are currently 7 genotypic variations, from $A$ to $G$, and also 4 main surface antigen subtypes: adw, ayw, adr, and ayr. There has been great interest in identifying the geographic distribution and prognosis associated with the various genotypes and subtypes. Although the serologic test is highly sensitive and specific, it does not detect cases of mutant hepatitis B, which is increasingly common worldwide due to resistance and vaccine escape, antiviral therapy, and immunosuppression, among other causes. Alterations in surface, polymerase, $\mathrm{X}$ region, core, and precore genes have been described. The main mutations occur in surface and in core/precore genes, also known as occult hepatitis, since its serologic markers of active infection (HBsAg) and viral replication (HBeAg) can be negative. Thus, mutation should be suspected when serologic tests to hepatitis B show control of immunity or replication coincident with worsened clinical status and exclusion of other causes of hepatitis.

KEY WORDS: Hepatitis B. Edidemiology. Serology. Mutation.

The hepatitis B virus (HBV) belongs to the Hepadnaviridae family and the Orthohepadnavirus genus. It measures 40 to $42 \mathrm{~nm}$, has an external surface envelope made up of proteins, lipids, and carbohydrates, and has a double-stranded circular DNA surrounded by a hexagonal core region. Although the virus is very resistant to heat and other physical agents, infected plasma can be inactivated by heating it for 5 hours at $60^{\circ} \mathrm{C}$. Hepatitis $\mathrm{B}$ virus infection may cause acute hepatitis (leading to cirrhosis), fulminant hepatitis with massive hepatic necrosis, an asymptomatic condition (with or without progression of the disease), or be a gateway to infection by the hepatitis Delta virus. ${ }^{1}$
The worldwide prevalence is estimated to be around 350 million chronic carriers, ${ }^{2}$ with an annual incidence of 300,000 new cases in the United States of America (USA). ${ }^{3}$ The overall prevalence estimates vary widely from low (2\%), as is found in Western Europe, North America, New Zealand, Australia, and Japan;,56 intermediate, as is found in Eastern Europe $(2 \%-7 \%)$ and India $(4 \%) ;^{5}$ high

From the Immunology Section, Central Lab Division, Hospital das Clínicas, Faculty of Medicine, University of São Paulo - São Paulo/SP, Brazil.

E-mail: vera@usp.br Received for publication on October 21, 2003.
(>8\%), as found in Africa, Southeast Asia, and China (15\% and 20\%), to very high, as found in Tibetans in $\mathrm{Ne}$ pal $(61 \%) .{ }^{4}$ Recent studies have shown an incidence of $6.6 \%$ in Istanbul, Turkey, ${ }^{8} 5.1 \%$ in Korea, ${ }^{9} 4 \%$ in Singapore, ${ }^{10}$ and $0.005 \%$ in Guangdong Province, China. ${ }^{11}$ In Latin America, the highest rates were found in the Dominican Republic $(21.4 \%)$ and in Brazil $(7.9 \%)$, followed by Venezuela (3.2\%) and Argentina (2.1\%). The lowest ones were found in Mexico (1.4\%) and Chile $(0.6 \%){ }^{12}$

Among the Brazilian regions, there are variations from $66.1 \%$ in Western Amazon, ${ }^{13}$ which is considered highly endemic for $\mathrm{HBV}^{7} 40 \%$ in Rio de Janeiro, ${ }^{14} 21 \%$ in Manaus, and up to 
$1.2 \%$ in Fortaleza. A study carried out in the Afro-descendant community in Mato Grosso do Sul revealed a prevalence of $42.7 \%,{ }^{15}$ and a prevalence of $50.7 \%$ was found in individuals with clinical evidence of hepatitis in Goias. ${ }^{16}$

According to data from the Brazilian Ministry of Health in the report "Indicadores de Dados Básicos Brasil 2001" (IDB-2001), ${ }^{17}$ there was an incidence of 7087 new cases in 2000, 540 of those in the state of São Paulo. According to data from the National Immunization Program, there was a vaccine coverage of 2,710,493 inhabitants, with $23,157,823$ doses administered in the whole country in $1999 .{ }^{18}$

The virus is transmitted especially through bodily fluids, such as semen, saliva, sweat, tears, or breast milk. During pregnancy, the virus may be transmitted to the fetus by crossing the placental barrier or also through cellular transmission. ${ }^{19}$ Although there is evidence of HBV infection in animals, there is no evidence of zoonotic transmission. ${ }^{20}$

The primary risk categories for infection by HBV are transfusions, blood derivates, dialysis, needle accidents among health-care professionals, intravenous drug abuse, and among homosexual individuals. Data published in 2002 showed an active infection with HBV of about $1.7 \%$ of 3556 heath-care workers in Chandirgarh, China. ${ }^{21}$ In Lagos, Nigeria, a study in 2000 found a prevalence of active infection by HBV of $25.7 \%$ in surgeons compared to $15 \%$ in administrative staff (control group). ${ }^{22}$

Vertical transmission is common in endemic regions such as Africa and Southeast Asia. ${ }^{3}$ A report from CDC (Centers for Disease Control and Prevention) in the United States estimated an incidence of $0.60 \%$ among pregnant white non-Hispanics, $0.97 \%$ among black non-Hispanics, $0.14 \%$ among Hispanics, and 5.79\% among Asians. A factor associated with increased rates was not receiving prenatal care. ${ }^{23}$ Another study conducted in Saudi Arabia found HBV causing 15\% of the sporadic acute viral hepatitis in pregnancy. ${ }^{24}$ Infants who acquire HBV perinatally have up to a $90 \%$ risk of developing HBV infection. ${ }^{25}$

Figure 1 shows the HBV genome. Proteins of greater importance produced by the HBV are:

- Nucleocapsid core protein $(\mathrm{HBcAg})$, which is not detectable in the serum;

- Long polypeptide "e" (AgHBe), which is transcribed from the core and precore genomic regions during active viral replication;

- Envelope glycoprotein (HBsAg) indicating active infection;

- A DNA polymerase with reverse transcriptase activity used by the virus upon cell infection;

- A protein from the $\mathrm{X}$ region that is necessary for replication and transcriptional transactivation of the viral genes and has a key role in the development of hepatocellular carcinoma (HCC).

Envelope glycoprotein contains a constant and group-specific epitope designated "a" and at least 2 variable epitopes, which are group-specific: "d" or " $y$ " and " $w$ " or "r", allowing for the identification of 4 antigenic

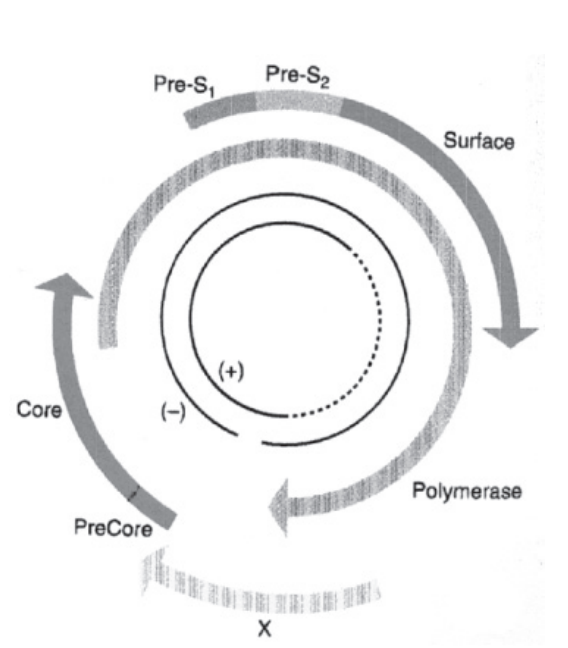

Figure 1 - Representation of DNA- Hepatitis B virus structure: adapted from Robbins,

Pathologic Basis of Disease, 1999, pg 858.

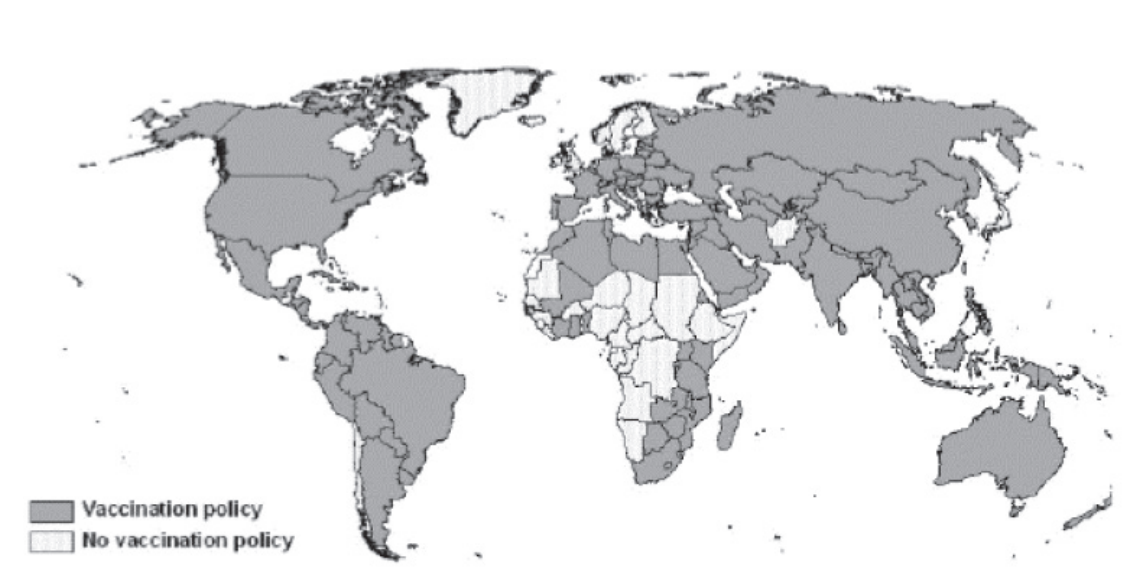

Figure 2 - Global vaccination coverage against H hepatitis B virus. World Health Organization,
2003.

Figure 2 - Global vaccination coverage against H hepatitis B virus. World Health Organization,
2003.

subtypes: adw, ayw, adr, and ayr. The ad subtypes are frequently found in asymptomatic individuals, whereas in the acute form the ay and ad subtypes may be found. A study in Goias (2002) found in individuals with clinical evidence of hepatitis a laboratory confirmation of ay and ad subtype prevalences of $23.5 \%$ and $62.7 \%$, respectively. ${ }^{16}$ The ay subtype is found in drug abusers and dialysis patients.

Currently, enzyme immunoassay methods (EIA) are available for subtype determination. These assays have several applications such as for large epidemiologic studies and as a substitute for nucleotide sequencing, which is not adapted for large-scale 
screening and not applicable on samples from nonviremic HBV carriers. ${ }^{26}$

There are 7 genotypic variations for HBV, named from $A$ to $G,{ }^{1}$ which have been associated with geographic distribution and with the progression of hepatic disease. The current tendency is to identify the more prevalent type to correlate to clinical findings. In southern Taiwan, the most common genotypes found were $B(60 \%)$ and $C$ (34\%), the latter being associated with more severe liver disease. ${ }^{27}$ However, the life-long risk of progression to advanced fibrosis and development of HCC may not differ among genotypes $B$ - and $C$-related chronic liver disease. ${ }^{28} \mathrm{~A}$ retrospective study done in Amsterdam from 1992 to 1997 associated genotype $A$ with homosexual men and genotype $D$ with intravenous drug users. ${ }^{29}$

The mechanism of injury after infection of the hepatocytes by HBV is not clearly established. Some evidence indicates that cytotoxic $\mathrm{T}$ cells directed towards the $\mathrm{HBcAg}$ antigen that is expressed on the cell surface may lead to hepatocyte destruction.

The asymptomatic incubation period varies from 4 to 26 weeks, followed by acute disease lasting from a few weeks to 6 months. In the posttransfusional infections, the incubation period may vary from 12 to 14 weeks.

The serologic markers are:

1. HBsAg — appears before the onset of symptoms, peaks during overt disease, and declines after 3 to 6 weeks;

2. HBeAg-appears in the serum indicating active viral replication. There is a significant correlation of HBeAg with HBV DNA (through PCR) and DNA polymerase;

3. Anti-HBc IgM-detectable in the serum shortly after the onset of symptoms, along with the elevation of serum transaminases and HBsAg and HBeAg. Anti-HBc IgM represents the first sign of an immune response after infection by the HBV, since it comes before the detection of anti-HBs and antiHBe. Over ensuing months, IgM is replaced by anti-HBc IgG. If HBsAg or HBeAg cannot be detected, anti-HBc may the only serologic marker that points towards a present or past $\mathrm{HBV}$ infection, as well as potentially contaminated blood. Thus, anti-HBc is a serologic marker for contact with HBV.

4. Anti-HBe-detectable in sera soon after the decline of $\mathrm{HBeAg}$, indicating the peak of acute disease and suggesting that the disease is near remission, with titers declining after 20 weeks;

5. Anti-HBs-its levels do not decline until acute disease is over and may even last for a lifetime, conferring immunity.

In adults, $90 \%$ to $95 \%$ of HBV infections have a spontaneous remission, with anti-HBc and anti-HBs detected in serologic tests for a long period. In asymptomatic carriers, HBsAg may be present alone, without viral replication and hepatic damage. Patients with a chronic evolution $(5 \%-10 \%)$ may present with a persistent chronic hepatitis of a self-limiting nature or, as in $3 \%$ of the cases, with active replication and poor outcome, characterized by the presence of $\mathrm{HBsAg}, \mathrm{HBeAg}$, HBV DNA, and usually total anti-HBc. Progressive liver damage may occur, leading to cirrhosis and HCC, increasing the risk of death. ${ }^{30} \mathrm{An}$ Indian study found HBV infection in $70 \%$ of the cases of chronic hepatitis, $80 \%$ of hepatic cirrhosis, and $60 \%$ of HCC. ${ }^{5} \mathrm{Nev}-$ ertheless, these situations can be simply avoided with mass vaccination program. $^{31}$

Two types of products are available for prophylaxis against HBV infection. Hepatitis B immune globulin (HBIG) provides temporary protection (ie, 3 to 6 months) and is indicated only in certain postexposure settings, and hepatitis B vaccine provides longterm protection against $\mathrm{HBV}$ infection and is recommended for both preexposure and postexposure prophylaxis. $^{73}$

Hepatitis B immune globulin is prepared from plasma known to contain a high titer of antibody against HBsAg (anti-HBs). In the United States, HBIG has an anti-HBs titer of $>100,000$ by radioimmunoassay. The human plasma from which HBIG is prepared is screened for antibodies to HIV; in addition, the process used to prepare HBIG inactivates and eliminates HIV from the final product. There is no evidence that HIV can be transmitted by HBIG. ${ }^{79,80}$

Vaccination is highly effective. Hepatitis B vaccines are composed of the HBsAg polypeptide that is produced in yeasts by the recombinant DNA technique or is artificially synthesized, and they are packaged to contain 10 to 40 ug of HBsAg protein/ $\mathrm{mL}$ after adsorption to aluminum hydroxide $(0.5 \mathrm{mg} / \mathrm{mL})$; thimerosal (1:20,000 concentration) is added as a preservative. ${ }^{73}$ The recommended series of 3 intramuscular doses of hepatitis $\mathrm{B}$ vaccine induces a protective antibody response with $90 \%$ to $95 \%$ efficacy in preventing HBV infection and its chronic sequelae. Currently licensed hepatitis $B$ vaccines include Recombivax $\mathrm{HB}^{\circledR}$ and Engerix- ${ }^{\circledR}{ }^{\circledR}{ }^{75}$ Initially administered to higher risk populations, such as health-care professionals, contacts to chronic carriers, newborns from infected mothers, and homosexual men, the vaccine protected many individuals but had little impact on the total number of infected persons. Thus, a pediatric vaccine was manufactured that was given along with the MMR vaccine to children in the high-risk groups, with a WHO recommendation for all countries to integrate hepatitis B vaccination into their universal childhood vaccination pro- 
grams by $1997 . .^{73}$ It is known that childhood vaccination can protect children against fulminant hepatitis and $\mathrm{HCC}^{1}$; however, to prevent perinatal HBV transmission, the first dose of vaccine should be administered within the first 24 hours after birth. ${ }^{73,74}$ Unpublished data from the CDC from 2003 shows that approximately $21 \%$ of HBV-related deaths result from infection acquired in the perinatal period and $48 \%$ from infection acquired in early childhood (age <5 years). Therefore, vaccination of infants and children is the highest priority for hepatitis B vaccination programs. Some examples of vaccination program effectiveness include the Canadian results, with a HBV prevalence of $0.0038 \%$ during the period 1993 to $1995^{33}$, and the United States results, with a decline of $76.1 \%$ after 11 years of the program, having rates of $0.033 \%$ in $1998 .^{3}$ In The Gambia, the prevalence of chronic infection among children declined from $10.0 \%$ to $0.6 \%$ after implementation of universal infant hepatitis B vaccination. ${ }^{76}$ Similar declines in prevalence of chronic infection associated with infant and childhood hepatitis B vaccination have been demonstrated in China, Indonesia, Senegal, and Thailand, and among Alaska Natives. ${ }^{77,78}$ According to the WHO estimate, a total of 151 (79\%) of 192 member states had adopted universal childhood hepatitis B vaccination policies. In the $6 \mathrm{WHO}$ regions, the proportion of children aged $<1$ year who were vaccinated fully was $65 \%$ in the Western Pacific Region, 58\% in the Americas Region, $45 \%$ in the European region, $41 \%$ in the Eastern Mediterranean region, $9 \%$ in the Southeast Asia region, and 6\% in the African region. Even so, only $32 \%$ of children aged $<1$ year were vaccinated fully with the 3-dose hepatitis B vaccination series. ${ }^{75}$

Serologic tests carried out after immunization are intended to evaluate immunity, identifying nonresponsive or weak-response individuals. A response is considered absent whenever anti-HBs titers are less than $10 \mathrm{UI} / \mathrm{L}$ and weak when titers are less than 100 $\mathrm{UI} / \mathrm{L}^{36}$. Immunized people may lose anti-HBs antibodies over variable courses of time, and initial antibody concentration after immunization may allow the prediction of the period during which the person will be immune as well as the scheduling of a date for revaccination.

Recent innovations have included the 2-dose, $10 \mathrm{mg}$ Recombivax $\mathrm{HB}^{\circledR}$ regimen for those who are 11 to 15 years old and Twinrix ${ }^{\circledR}$, a combination hepatitis $\mathrm{A}$ and $\mathrm{B}$ vaccine. ${ }^{81}$ Goals for global hepatitis $\mathrm{B}$ vaccination are for the vaccine to be introduced in all countries by 2007 , for coverage with the 3-dose hepatitis $\mathrm{B}$ vaccination series to reach $90 \%$ by $2010,{ }^{72}$ and for the total control in first half of the $21 \mathrm{st}$ century. ${ }^{1}$

Figure 3 shows a current algorithm for serological diagnosis of HBV used in Immunological Section of Central Clinical Laboratory Division of Clinic Hospital of University of São Paulo Medical School (HC-FMUSP). The serologic marker for contact is total anti$\mathrm{HBc}$ (IgM and IgG). A negative test indicates no previous contact with $\mathrm{HBV}$ and thus excludes current infection. A positive test requires evaluation for anti-HBs and HbsAg, which will indicate either immunity or active infection. If the latter is confirmed, the presence of anti-HBe, HbeAg, and anti-HBc

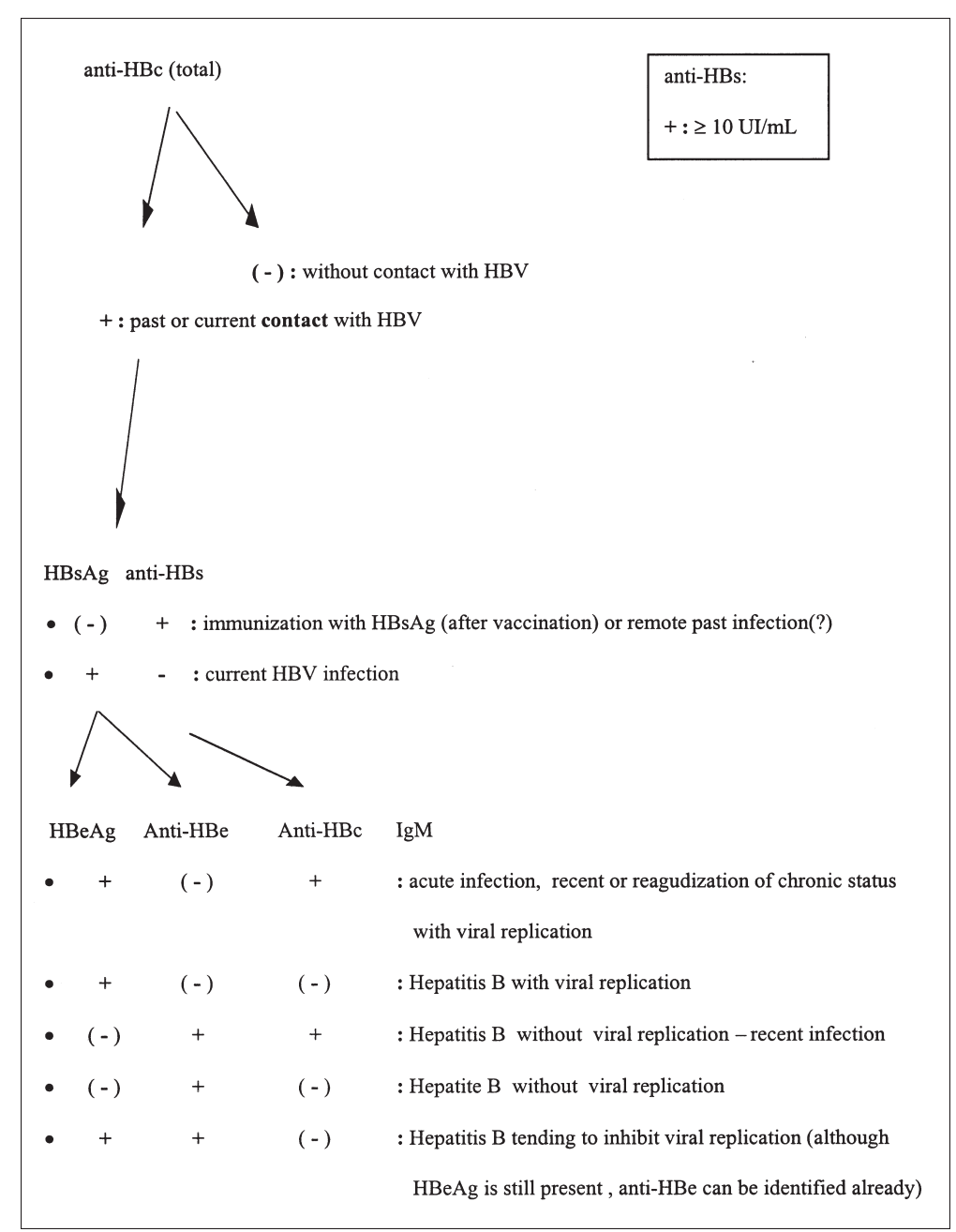

Figure 3 - Suggested algorithm for serologic diagnosis of Hepatitis B virus (HBV). 
(IgM) must be determined, which will indicate the probable evolution of the disease. Anti-HBs tests can be performed separately when the purpose is to evaluate the immunological status of a patient against $\mathrm{HBV}$ infection, ie, whether there was previous vaccination or not.

Although these EIA tests are highly sensitive and specific, their interpretation should be done considering clinical and epidemiological status. In cases with serologic markers indicating immunity or cessation of replication with other causes of hepatitis excluded, a genomic mutation of HBValso known as occult hepatitis-has to be suspected. The presence of normal transaminase and low levels of HBVDNA does not exclude the existence of resistant mutants. ${ }^{37}$

Mutations have been described in several regions of viral DNA, including surface gene, $\mathrm{X}$ gene, core gene, polymerase gene, and precore gene. The main mutations occur in the surface genes, which encode epitopes neutralized by antibodies, and in precore/ core genes, which encode epitopes presented to CD8 T cells. ${ }^{39}$

Genetic transformation can be detected by the following tests: PCR (polymerase chain reaction), ${ }^{39}$ bDNA (branched DNA assay), ${ }^{40}$ PCR-RFLP (PCR followed by restriction length polymorphism assay), ${ }^{41} \mathrm{msPCR}$ (mutant-specific PCR), ${ }^{42}$ CMSSA (competitive mutation site-specific assay), ${ }^{41}$ or MSSA (mutant site-specific assay). ${ }^{43}$

Serologic assays do not reveal genomic transformation; PCR is more sensitive than bDNA; ${ }^{44}$ CMSSA is more sensitive and specific than PCRRFLP, mainly for detecting precore mutants; and msPCR is more sensitive and specific than other similar assays. In addition, other PCR variations are being tested to detect mutants. SP-PCR (sequence-specific PCR) and LDRPCR (limiting dilution-cloning PCR) are some examples, the latter having the greatest sensitivity for detecting variants in the surface antigen. ${ }^{45}$

Surface antigen mutations occur in pre-S1/2 and S regions, also known as escape or immune escape mutations. ${ }^{46}$ They are characterized by either positive $\mathrm{HBsAg}$ and anti-HBs or negative HBsAg with positive anti-HBs, occurring mainly in chronic hepatitis carriers. ${ }^{48}$ An international study that involved investigators from CDC and WHO demonstrated a prevalence of $51 \%$ in variants of surface antigen among infants with chronic HBV infection. ${ }^{45}$ Pre-S1 epitope has been possibly related to virus replication (positive $\mathrm{HBeAg}$ ), even with the presence of anti-HBe. In turn, the pre-S2 epitope has not been related to virus replication levels. ${ }^{49}$ But in the case of the $S$ epitope, this mutation decreases or abolishes the HBsAg properties, probably inhibiting its transcription levels. This explains a persistence in the natural course of the $\mathrm{HBV}$ infection ${ }^{50}$ coincidentally with having negative HBsAg and positive anti-HBs serologic results. ${ }^{48}$ In addition, advanced hepatic fibrosis and diminished response to interferon alpha can occur. ${ }^{51}$

Precore/core gene transformations have generally been associated with chronic HBV infection, ${ }^{38,41,52-58}$ having serologic results with either positive HBeAg ${ }^{40-42,47,52,53,57-60}$ or negative HBeAg. ${ }^{54}$ The latter have been more frequently reported, ${ }^{46,61}$ also known as an e-minus mutation. Frequently, the mutation occurs after seroconversion to anti-HBe. ${ }^{42}$

Mutations that produce a stop codon in the precore region of $\mathrm{HBV}$ DNA are usually point mutations, with a single nucleotide (nt) substitution. Currently, mutations have been reported in nt 1762 (A to $\mathrm{T}$ ), 1764 ( $\mathrm{G}$ to A), 1835 (A to C), 1896 ( $\mathrm{G}$ to $\mathrm{A}$ ), 1857 , and 1897 among others. ${ }^{38,62,63}$ One of the most prevalent is the precore nt 1896 mutation. ${ }^{38,62,63}$ Sero- logic markers include positive $\mathrm{HBeAg} /$ anti-HBe ${ }^{39,41,47,58}$ as well as negative HBeAg, ${ }^{38,53,54}$ both in chronic hepatitis B patients. Precore mutations can also be related to fulminant or severe hepatitis, and their absence in HBeAgpositive patients indicates a good prognosis. ${ }^{43,62}$

Core mutations possibly alter the transcription factor-binding site, increasing the activity of core promoter related to $\mathrm{HBV}$ reactivation, ${ }^{57} \mathrm{HCC}$, and hepatic cirrhosis. Investigators from China have reported that the presence of core promoter mutations were significantly more common in HCC patients than asymptomatic carriers and also were more common in patients with cirrhosis and chronic hepatitis. ${ }^{64}$ The prevalence of both types of chronic hepatitis e-minus (e-CHB) mutations varies according to worldwide region. A literature review, which included 50 studies, found the highest rates in Far East and Mediterranean countries $^{54}$ - about 33\%-followed by $15 \%$ in Asia Pacific and $14 \%$ in the USA and Northern Europe. ${ }^{65}$ The precore stop-codon variant was detected in a median of $60 \%$ (range 0 $100 \%$ ) of $\mathrm{HBeAg}$-negative patients overall, $92 \%$ in the Mediterranean, $50 \%$ in Asia Pacific, 27\% in Gambia and $25 \%$, and $24 \%$ in the USA and Northern Europe. ${ }^{63,65}$

The main causes of genetic variation have been related to the escape mechanism and to viral resistance and have been associated with:

1. Natural infection (mainly novel surface mutations) $)^{48}$;

2. Vaccination (mutation in surface antigen $^{47,66-68}$ ) or presence of antibodies against dominant B cell epitopes $^{69}$;

3. Antiviral therapy (activation of HBV genetic mutant variants during lamivudine treatment or chemotherapy or associated with acute liver disease $\left.{ }^{62,66,67,69}\right)$. A study carried out in India found a fre- 
quency of $29 \%$ of lamivudine-resistant HBV variants with mutations in the surface and polymerase genes 18 month after lamivudine therapy. ${ }^{37}$ Another study relates the reactivation of HBV with a precore mutation (nt 1896) with cytotoxic chemotherapy, suggesting the need for a prophylactic use of lamivudine before and during the chemotherapy for patients with precore mutant varieties of $\mathrm{HBV}^{62}$;

4. Immunosuppression associated with $\mathrm{HBV}$ infection (mutation in different types and positions: core, pre-S1/2, X gene $^{70}$ );

5. Chronic hepatis B followed by liver, ${ }^{56-71}$ renal, ${ }^{53,59}$ or bone marrow ${ }^{56}$ transplantation;

In most of the cases, genetic variation occurs concomitant with wild strains, it rarely occurs isolated. ${ }^{47,54}$

Figure 4 suggests an algorithm for serologic diagnosis with suspicion of mutation, which must be confirmed with further exams, such as molecular typing.

Mutations can therefore affect the natural course of HBV infection, viral clearance, and antiviral therapy response. The exact contributions of specific genetic variations, diagnosis, and proper therapy still have to be estabilished..$^{47}$

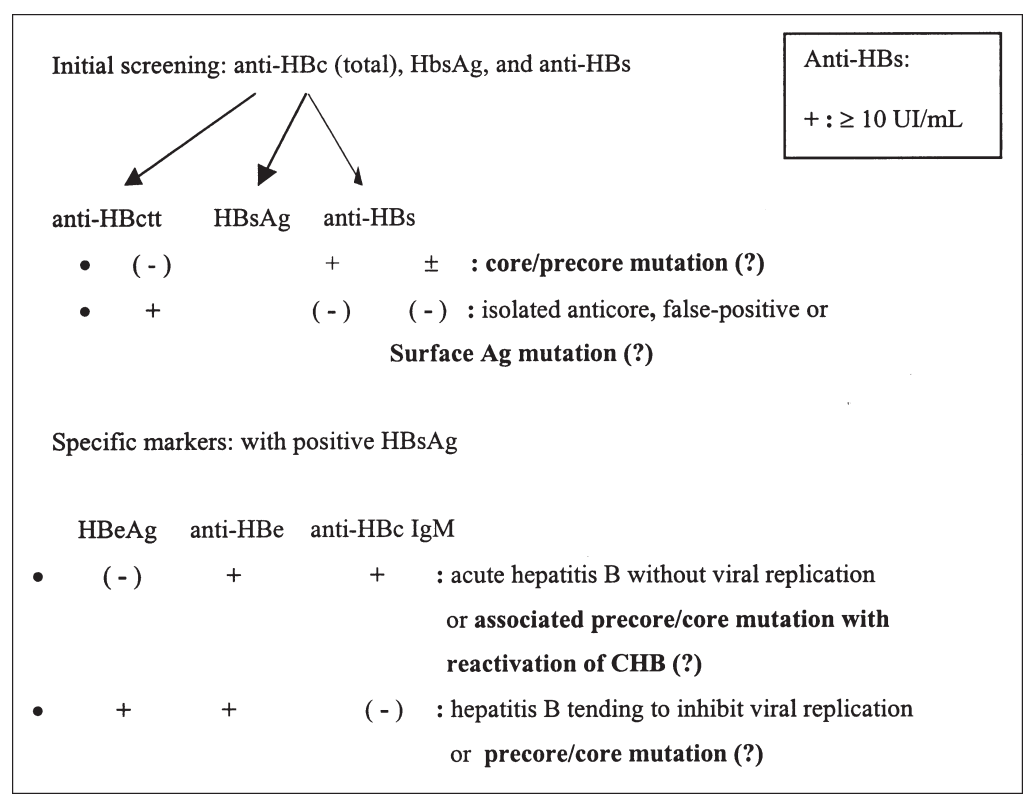

Figure 4 - Suggestion of algorithm for anomalous serologic markers. (suspicion of Hepatitis B virus (HBV) mutants).

\section{RESUMO}

Khouri ME e col. Hepatite B: considerações epidemiológicas, imunológicas e sorológicas com ênfase em mutação. Rev. Hosp. Clí. Fac. Med. S. Paulo 59(4):216-224, 2004.

A prevalência mundial do vírus da Hepatite B é estimada em cerca 350 milhões de infectados cronicamente, tendo distribuição bastante variada com prevalências baixas desde inferiores a dois por cento, como Europa Ocidental, América do Norte, Nova Zelândia, Austrália e Japão - até altas, superiores a oito por cento como encontradas na África, Sudeste Asiático e China. No Brasil, a prevalência mé- dia é em torno de $8 \%$. São descritos atualmente sete variações genotípicas do HBV, nomeadas de A a G, e quatro subtipos principais de antígenos de superfície: "adw", "ayw", "adr "e "ayr", existindo um grande interesse em identificar quais os subtipos e genotipos mais prevalentes a fim de correlacioná-los com manifestações clínicas e distribuição geográfica. Apesar do diagnóstico sorológico ser normalmente bastante sensível e específico, este não detecta casos de Hepatite $\mathrm{B}$ mutantes, cada vez mais freqüentes atualmente devido a escape e resistência de vacinação, terapias antivirais, imunossupressão dentre outras. São descritas alterações genômicas no gene de superfície (envelope); gene X; gene do "core"; gene polimerase e gene "pré-core". As principais mutações ocorrem nos genes de superfície e nos genes "pré-core/core", podendo também ser conhecidas como hepatite oculta, uma vez que os marcadores de infecção ativa (AgHBs) e replicação viral $(\mathrm{AgHBe})$ podem estar negativos. Assim, deve-se suspeitar de mutação viral nos casos em que a sorologia para a hepatite $\mathrm{B}$ indica imunidade ou parada da replicação com o quadro clínico evoluindo mal, excluído outras causas de hepatites.

UNITERMOS: Hepatite B. Epidemiologia. Serologia. Mutação. 
1. Di Marco V, Lo Iacono O, Camma C, Vaccaro A, Giunta M, Martorana G, et al. The long-term course of chronic hepatitis B. Hepatology 1999;30:257-64.

2. Kao JH, Chen DS. Global control of hepatitis B virus infection. Lancet Infect Dis 2002;2(7):395-403.

3. Crawford J. The liver and the biliary tract. In: COTRAN RS, KUMAR V, COLLINS T - Pathologic Basis of Disease Robbins. $6^{\text {th }}$ ed. Philadelphhia, Saunders, 1999, pp. 857-62.

4. Shrestha SM, Takeda N, Tsuda F, Okamoto H, Shrestha S, Shrestha VM. High prevalence of hepatitis B virus infection amongst Tibetans in Nepal. Trop Gastroenterol 2002;23(2):63-5.

5. Tandon BN, Acharya SK, Tandon A. Epidemiology of hepatitis B virus infection in India. Gut 1996:38 Suppl 2:S56-9.

6. Chen CJ, Wang LY, Yu MW. Epidemiology of hepatitis B virus infection in the Asia-Pacific region. J Gastroenterol Hepatol 2000;15:E3-E6.

7. Maddrey WC. Hepatitis B. An important public health issue. Clin Lab 2001;47:51-5.

8. Erden S, Buyukozturk S, Calangu S, Yilmaz G, Palanduz S, Badur S. A study of serological markers of hepatitis $B$ and $C$ viruses in Istanbul, Turkey. Med Princ Pract 2003;12(3):184-8.

9. Lee DH, Kim JH, Nam JJ, Kim HR, Shin HR. Epidemiological findings of hepatitis B infection based on 1998 National Health and Nutrition Survey in Korea. J Korean Med Sci 2002;17(4):457-62.

10. James L, Fong CW, Foong BH, Wee MK, Chow A, Shum E, et al. - Hepatitis B Seroprevalence Study 1999. Singapore Med J 2001;42(9):420-4.

11. Huang P, Ye G, Zhong J, Sha Q. Assessment of current epidemiological status of viral hepatitis in Guangdong Province, China. Southeast Asian J Trop Med Public Health. 2002;33(4):832-6.

12. Tanaka J. Hepatitis B epidemiology in Latin America. Vaccine 2000;18:S17-S19.

13. de Paula VS, Arruda ME, Vitral CL, Gaspar AM. Seroprevalence of viral hepatitis in riverine communities from the Western Region of the Brazilian Amazon Basin. Mem Inst Oswaldo Cruz 2001;96(8):1123-8.

14- Lewis-Ximenez LL, do O KM, Ginuino CF, Silva JC, Schatzmayr HG, Stuver S, et al. Risk factors for hepatitis B virus infection in Rio de Janeiro, Brazil. BMC Public Health 2002;2(1):26.

15. Motta-Castro AR, Yoshida CF, Lemos ER, Oliveira JM, Cunha RV, Lewis-Ximenez LL, et al. Seroprevalence of hepatitis B virus infection among an Afro-descendant community in Brazil. Mem Inst Oswaldo Cruz 2003;98(1):13-7. Epub 2003 Apr 09 .

16. Silva C de O, Azevedo Mda S, Soares CM, Martins RM, Ramos $\mathrm{CH}$, Daher RR, et al. Seroprevalence of hepatitis B virus infection in individuals with clinical evidence of hepatitis in Goiania, Goias. Detection of viral DNA and determination of subtypes. Rev Inst Med Trop Sao Paulo 2002;44(6):331-4.
17. Ministério da Saúde. Fundação Nacional de Saúde. Centro Nacional de Epidemiologia. Indicadores e Dados Básicos 2001.

18. Ministério da Saúde. Programa Nacional de Vacinações. Sistema de Informações do Programa Nacional de Imunizações (SIPNI). Indicadores e Dados Básicos 1998.

19. Xu DZ, Yan YP, Zou S, Choi BC, Wang S, Liu P, et al. Role of placental tissues in the intrauterine transmission of hepatitis $\mathrm{B}$ virus. Am J Obstet Gynecol 2001;185(4):981-7.

20. Noppornpanth S, Haagmans BL, Bhattarakosol P, Ratanakorn P, Niesters HG, Osterhaus AD, et al. Molecular epidemiology of gibbon hepatitis B virus transmission. J Gen Virol 2003;84(Pt 1):147-55.

21. Duseja A, Arora L, Masih B, Singh H, Gupta A, Behera D, et al. Hepatitis B and C virus-prevalence and prevention in health care workers. Trop Gastroenterol 2002;23(3):125-6.

22. Belo AC. Prevalence of hepatitis B virus markers in surgeons in Lagos, Nigeria. East Afr Med J 2000;77(5):283-5.

23. Euler GL, Wooten KG, Baughman AL, Williams WW. Hepatitis B surface antigen prevalence among pregnant women in urban areas: implications for testing, reporting, and preventing perinatal transmission. Pediatrics. 2003; 111(5 Part 2):1192-7.

24. Khuroo MS, Kamili S. Aetiology, clinical course and outcome of sporadic acute viral hepatitis in pregnancy. J Viral Hepat $2003 ; 10(1): 61-9$

25. Broderick AL, Jonas MM. Hepatitis B in children. Semin Liver Dis 2003; 23(1):59-68.

26. Laperche S, Girault A, Beaulieu MJ, Bouchardeau F, Courouce AM. Determination of hepatitis B virus subtypes by an enzyme immunoassay method using monoclonal antibodies to typespecific epitopes of HBsAg. J Viral Hepat 2001;8(6):447-53.

27. Lee CM, Chen CH, Lu SN, Tung HD, Chou WJ, Wang JH, et al. Prevalence and clinical implications of hepatitis B virus genotypes in southern Taiwan. Scand J Gastroenterol 2003;38(1):95-101.

28. Sumi H, Yokosuka O, Seki N, Arai M, Imazeki F, Kurihara T, et al. Influence of hepatitis B virus genotypes on the progression of chronic type B liver disease. Hepatology 2003;37(1):19-26.

29. van Steenbergen JE, Niesters HG, Op de Coul EL, van Doornum GJ, Osterhaus AD, Leentvaar-Kuijpers A, et al. Molecular epidemiology of hepatitis B virus in Amsterdam 1992-1997. J Med Virol 2002;66(2):159-65.

30. Zuckerman JN, Zuckerman AJ. Hepatitis viruses and TT virus. In : LEIDINGAN JGG, WARREL DA - Concise Oxford Textbook of Medicine. $1^{\text {st }}$ ed. New York, Oxford Press, 2000. pp. 1553-55.

31. Rizzetto M, Zanetti AR. Progress in the prevention and control of viral hepatitis type B: closing remarks. J Med Virol 2002;67(3):463-6.

32. Racz ML, Candeias JN. Viroses Hepáticas. In: Trabulsi LR, Alberthum F, Gompertz OF, et al. Microbiologia Básica. $3^{\text {th }}$ ed. São Paulo,Atheneu1999. pp. 515- 518. 
33. Elsaadany S, Gully P, Giulivi A. Hepatitis A, B, and C in Canada. Results from the National Sentinel Health Unit Surveillance System, 1993-1995. Can J Public Health 2002;93(6):435-8.

34. Goldstein ST, Alter MJ, Williams IT, Moyer LA, Judson FN, Mottram K, et al. Incidence and risk factors for acute hepatitis B in the United States, 1982-1998: implications for vaccination programs. J Infect Dis 2002;185(6):713-9. Epub 2002 Feb 28.

35. Alter MJ - Epidemiology and prevention of hepatitis B. Semin Liver Dis 2003;23(1):39-46.

36. Zuckerman JN. Nonresponse to hepatitis B vaccines and kinetics of anti-HBs production. J Med Virol 1996 ; 50, 283-288.

37. Wakil SM, Kazim SN, Khan LA, Raisuddin S, Parvez MK, Guptan $\mathrm{RC}$, et al. Prevalence and profile of mutations associated with lamivudine therapy in Indian patients with chronic hepatitis B in the surface and polymerase genes of hepatitis B virus. J Med Virol 2002;68(3):311-8

38. Protzer U, Goergen B, Hopf U, Neuhaus P, Konig V, Meyer zum Buschenfelde $\mathrm{KH}$, et al. Pre-core mutants of hepatitis B virus in patients receiving immunosuppressive treatment after orthotopic liver transplantation. J Med Virol 1996; 50 (2):135-44.

39. Asahina Y, Enomoto N, Ogura Y, Kurosaki M, Sakuma I, Izumi $\mathrm{N}$, et al. Sequential changes in full-length genomes of hepatitis $\mathrm{B}$ virus accompanying acute exacerbation of chronic hepatitis B. J Hepatol 1996;25(6):787-94.

40. Moradpour D, Blum HE - Clinical significance of hepatitis B virus mutants. Schweiz Rundsch Med Prax 1998;87(6):205-9.

41. Ichikawa T, Takagi H, Kinoshita M, Shimoda R, Nagamine T, Mori M. Quantitative analysis of hepatitis B virus precore mutant in hepatitis type B. Tohoku J Exp Med 1998; 186 (4):323-33.

42. Blackberg J, Kidd-Ljunggren K. Genotypic differences in the hepatitis $\mathrm{B}$ virus core promoter and precore sequences during seroconversion from $\mathrm{HBeAg}$ to anti-HBe. J Med Virol 2000;60(2):107-12.

43. Shiraki K, Hamada M, Sugimoto K, Ito T, Yamanaka T, Wagayama $\mathrm{H}$, et al. Detection of precore-mutant hepatitis B virus genome in patients with acute and fulminant hepatitis using mutation site-specific assay (MSSA). Hepatogastroenterology 2002;49(47):1352-6.

44. Pichoud C, Berby F, Stuyver L, Petit MA, Trepo C, Zoulim F. Persistence of viral replication after anti-HBe seroconversion during antiviral therapy for chronic hepatitis B. J Hepatol 2000;32(2):307-16

45. Nainan OV, Khristova ML, Byun K, Xia G, Taylor PE, Stevens $\mathrm{CE}$, et al. Genetic variation of hepatitis B surface antigen coding region among infants with chronic hepatitis B virus infection. J Med Virol 2002;68(3):319-27.

46. Blum HE, Moradpour D, von Weizsacker F, Wieland S, Peters T, Rasenack JW. Hepatitis B virus mutants-clinical significance. Z Gastroenterol 1997;35 (5):347-55.

47. Lopez-Alcorocho JM, Moraleda G, Bartolome J, Castillo I, Cotonat $\mathrm{T}$, Aguilar J, et al. Analysis of hepatitis B precore region in serum and liver of chronic hepatitis B virus carriers. J Hepatol 1994;21(3):353-60
48. Banerjee K, Guptan RC, Bisht R, Sarin SK, Khandekar P. Identification of a novel surface mutant of hepatitis $\mathrm{B}$ virus in a seronegative chronic liver disease patient. Virus Res 1999;65(2):103-9.

49. Zoulim F, Capel F, Berthillon P, Trepo C, Petit MA. Clinical and virological evaluation of the detection of pre-S1 and pre-S2 antigens in serum from patients with chronic hepatitis B. Gastroenterol Clin Biol 1995;19(12):970-5.

50. Ogura Y, Kurosaki M, Asahina Y, Enomoto N, Marumo F, Sato C. Prevalence and significance of naturally occurring mutations in the surface and polymerase genes of hepatitis B virus. J Infect Dis 1999;180 (5):1444-51.

51. Torbenson M, Thomas DL. Occult hepatitis B. Lancet Infect Dis 2002;2(8):479-86.

52. Ando T, Sugiyama K, Goto K, Miyake Y, Li R, Kawabe Y, et al. Age at time of hepatitis Be antibody seroconversion in childhood chronic hepatitis B infection and mutant viral strain detection rates. J Pediatr Gastroenterol Nutr 1999;29(5):5837.

53. Booth JC, Goldin RD, Brown JL, Karayiannis P, Thomas HC. Fibrosing cholestatic hepatitis in a renal transplant recipient associated with the hepatitis B virus precore mutant. J Hepatol 1995;22(4):500-3.

54. Bozdayi AM, Bozkaya H, Turkyilmaz A, Aslan N, Verdi H, Kence A, et al. Polymorphism of precore region of hepatitis B virus DNA among patients with chronic HBV infection in Turkey. Infection 1999; 27 (6):357-60.

55. Chan HL, Leung NW, Hussain M, Wong ML, Lok AS. Hepatitis B e antigen-negative chronic hepatitis B in Hong Kong. Hepatology 2000;31(3):763-8.

56. Cooksley WG, McIvor CA. Fibrosing cholestatic hepatitis and HBV after bone marrow transplantation. Biomed Pharmacother $1995 ; 49(3): 117-24$

57. Gerner P, Lausch E, Friedt M, Tratzmuller R, Spangenberg C, Wirth S. Hepatitis B virus core promoter mutations in children with multiple anti-HBe/HBeAg reactivations result in enhanced promoter activity. J Med Virol 1999;59(4):415-23.

58. Protzer-Knolle U, Knolle P, Schiedhelm E, Meyer zum Buschenfelde KH, Gerken G. Semiquantitative assessment of pre-core stop-codon mutant and wildtype hepatitis $\mathrm{B}$ virus during the course of chronic hepatitis B using a new PCRbased assay. Arch Viro 1996;141(11):2091-101.

59. Brind AM, Bennett MK, Bassendine MF. Nucleoside analogue therapy in fibrosing cholestatic hepatitis-a case report in an HBsAg positive renal transplant recipient. Liver 1998;18(2):134-9.

60. Oketani M, Oketani K, Xiaohong C, Arima T. Low level wildtype and pre-core mutant hepatitis $\mathrm{B}$ viruses and $\mathrm{HBeAg}$ negative reactivation of chronic hepatitis B. J Med Virol 1999;58(4):332-7.

61. Dienstag JL, Isselbacher KJ. Acute Viral Hepatitis. In: Braunwald E, Fauci AS, Kasper DL. Harrison's Principles of Internal Medicine. $15^{\text {th }}$ ed. United States, McGraw Hill, 2001, pp 17211736 
62. Dai MS, Lu JJ, Chen YC, Perng CL, Chao TY. Reactivation of precore mutant hepatitis B virus in chemotherapy-treated patients. Cancer 2001;92(11):2927-32.

63. Dumpis U, Mendy M, Hill A, Thursz M, Hall A, Whittle H, et al. Prevalence of HBV core promoter/precore/core mutations in Gambian chronic carriers. J Med Virol 2001;65(4):664-70.

64. Fang ZL, Yang J, Ge X, Zhuang H, Gong J, Li R, et al. Core promoter mutations (A(1762)T and G(1764)A) and viral genotype in chronic hepatitis B and hepatocellular carcinoma in Guangxi, China.J Med Virol 2002;68(1):33-40.

65. Funk ML, Rosenberg DM, Lok AS. World-wide epidemiology of HBeAg-negative chronic hepatitis B and associated precore and core promoter variants. J Viral Hepat 2002;9(1):52-61.

66- BRIND AM, BENNETT MK, BASSENDINE MF - Nucleoside analogue therapy in fibrosing cholestatic hepatitis-a case report in an HBsAg positive renal transplant recipient. Liver 1998;18(2):134-9.

67. Wang YM, Ng WC, Lo SK. Detection of pre-S/S gene mutants in chronic hepatitis B carriers with concurrent hepatitis B surface antibody and hepatitis B surface antigen. J Gastroenterol 1999;34(5):600-6.

68. Gaeta GB, Stornaiuolo G, Precone DF. Type B and D viral hepatitis: epidemiological changes in Southern Europe. Forum (Genova) 2001;1(2):126-33.

69. Pumpens P, Grens E, Nassal M. Molecular epidemiology and immunology of hepatitis B virus infection - an update. Intervirology 2002;45(4-6):218-32.

70. Preikschat P, Meisel H, Will H, Gunther S. Hepatitis B virus genomes from long-term immunosuppressed virus carriers are modified by specific mutations in several regions. J Gen Virol 1999;80(Pt 10):2685-91.

71. Protzer U, Trippler M, Ohl J, Knolle P, Duchmann R, Meyer zum Buschenfelde $\mathrm{KH}$, Gerken G. Rare pre-core stop-codon mutant nt. 1897 predominates over wide-spread mutant nt. 1896 in an unusual course of chronic hepatitis B. J Viral Hepat $1996 ; 3(3): 155-62$.
72. Global Alliance for Vaccines and Immunization. GAVI Milestones, 2003. Available at http://www.vaccinealliance.org/home/ General_Information/ About_alliance/Background/ milestones.php

73. CDC - Hepatitis B virus: a comprehensive strategy for eliminating transmission in the United States through universal childhood vaccination: Recommendations of the Immunization Practices Advisory Committee (ACIP). MMWR 1991;40(No. RR-13).

74. Yeoh EK, Young B, Chan YY, et al. Determinants of immunogenicity and efficacy of hepatitis B vaccine in infants. In: Hollinger FB, Lemon SM, Margolis HS, eds. Viral Hepatitis and Liver Disease. Baltimore, Maryland: Williams \& Wilkins, 1991.

75. CDC - Global Progress Toward Universal Childhood Hepatitis B Vaccination, 2003. MMWR 2003;52(36):868-870.Septe12, 2003 / 52(36);868-870 September 76. Viviani S, Jack A, Hall AJ, Maine N, Mendy M, Montesano R, et al. Hepatitis B vaccination in infancy in The Gambia: protection against carriage at 9 years of age. Vaccine 1999;17:2946-50.

77. Kane MA. Status of hepatitis B immunization programmes in 1998. Vaccine 1998;16:S104.

78. Harpaz R, McMahon BJ, Margolis HS, Shapiro CN, Havron D, Carpenter G, et al. Elimination of new chronic hepatitis B virus infections: results of the Alaska Immunization Program. J Infect Dis 2000;181:413-8.

79. CDC. Safety of therapeutic immune globulin preparations with respect to transmission for human T-lymphotrophic virus type III/lymphadenopathy- associated virus infection. MMWR 1986;35:231-3.

80. Wells MA, Wittek AE, Epstein JS, Marcus-Sekura C, Daniel S, Tankersley DL, et al. Inactivation and partition of human Tcell lymphotrophic virus, type III, during ethanol fractionation of plasma. Transfusion 1986;26:210-3.

81. Cassidy WM. Adolescent hepatitis B vaccination. A review. Minerva Pediatr 2001;53(6):559-66. 